\title{
Salamander using its prehensile tail - Bolitoglossa cf. nympha (Plethodontidae; sub-genus Nanotriton), Honduras
}

\author{
TOM W. BROWN ${ }^{1,2}$ \\ ${ }^{1}$ Operation Wallacea, Hope House, Old Bolingbroke, Lincolnshire PE23 4EX, UK \\ ${ }^{2}$ Kanahau Utila Research \& Conservation Facility, Isla de Utila, IB 34201, Honduras \\ *Author e-mail: tom@kanahau.org
}

$\mathrm{B}_{\varepsilon}^{\mathrm{o}}$ olitoglossa nympha Campbell, Smith, Streicher, Acevedo, \& Brodie 2010 is a diminutive salamander; snout-ventlength $<43 \mathrm{~mm}$, tail-length/SVL ratio 0.70-0.95 (Kohler, 2011). It occurs at low-to-mid elevations (275 to $1165 \mathrm{~m}$ asl) from Huehuetenango and Baja Verapaz provinces in Guatemala, through to Copán, Cortés, and Yoro in Honduras (Frost, 2020). The species belongs to a complex of four closely related bolitoglossine salamanders in the Bolitoglossa rufescens group (subgenus Nanotriton; Parra-Olea et al., 2004). In north-western Honduras, in-situ identification of Bolitoglossa (Nanotriton) is tentative given the occurrence of at least two cryptic taxa (B. nympha \& B. rufescens) in microsympatry; both these species being morphologically indistinguishable in the field (Hess et al., 2017). Species of Bolitoglossa (Nanotriton) primarily inhabit lowland tropical rainforest habitats, but are also associated with agricultural habitats such as banana plantations (Rovito et al., 2012 a\&b). They are primarily nocturnal and semi-arboreal, frequently climbing moist vegetation to use leaf-axil refugia and bromeliads (Rovito et al., 2012b). Unlike other Bolitoglossa, species of the subgenus Nanotriton are unique in having small robust bodies, with a tail length usually shorter than their SVL, and underdeveloped feet with extensive webbing (Parra-Olea et al., 2004; Kohler, 2011).

Previously, the tail of Bolitoglossa (Nanotriton) spp. has been linked to defensive strategies such as raising, posturing and autotomy (Arrivillaga \& Brown, 2018). However, the following note details $B$. cf. nympha using its tail to grasp and assist climbing following a flip and fall defensive manoeuvre. On 14 July 2016, c. 19.40 h, I encountered an adult Bolitoglossa (Nanotriton sp. - assumed to be B. nympha) active on streamside vegetation bordering agricultural land, in the lowland buffer region of Parque Nacional El Cusuco (PNC), Santo Tomas, Cortés, Honduras. The individual was climbing c. $2 \mathrm{~m}$ above ground, but when approached, flipped and dropped from its perch, then caught itself using the tail like a hook to grasp a stem c. $1 \mathrm{~m}$ below (Fig 1A). After dangling motionless for c. 1 minute, the tail was used to lever the body upwards and prevent the salamander from falling (Fig 1B). Such a mechanism might not only protect the salamander from an injurious fall, but could also fool a predator as to its whereabouts, assuming it to have fallen completely to the ground.

Long prehensile tails are a widespread adaptation among arboreal plethodontid salamanders (Duellman \& Trueb, 1986), but evidence of their use in assisted climbing, escape
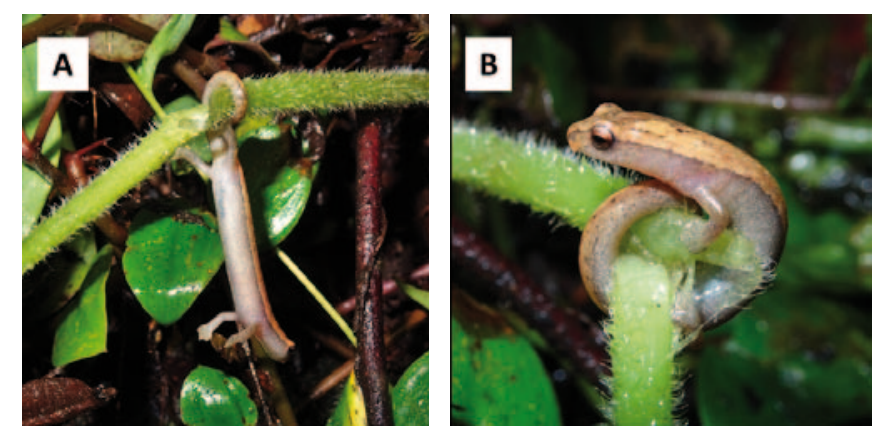

Figure 1. Nanotriton (B. cf. nympha) exhibiting caudal prehensility following a flip and fall escape, A. The salamander hanging momentarily after having caught itself using the tail to grasp a stem, B. The salamander levering itself back up onto the stem

and/or defence remains rare. Phillips \& Nicholson (2013) coined the term 'caudal prehensility' to define this behaviour in salamanders, reporting an observation of Bolitoglossa lignicolor using its tail in a hook-like fashion to catch itself following a flipping escape. Until now, B. lignicolor remained the only Bolitoglossa species in which this behaviour was reported definitively. The present observation demonstrates prehensility in $B$. cf. nympha, suggesting that even short tails like those of sub-genus Nanotriton are practical for locomotion and defence in an arboreal setting. Our collective studies call for more field observations in order to determine whether prehensility is widespread in bolitoglossine species.

\section{ACKNOWLEDGEMENTS}

A special thanks to the management, staff and local field guides of Operation Wallacea (UK) for facilitating biological research expeditions in PNC, Honduras, as well as to Dr. Tom Martin and Dr. Sean M. Rovito who provided helpful reviews of this note. This observation was made under permit number ICF-DVS-104-2016; ICF-193-2016, issued to Operation Wallacea by the Instituto Nacional de Conservación y Desarrollo Forestal, Áreas Protegidas y Vida Silvestre (ICF), Tegucicalpa, Honduras.

\section{REFERENCES}

Arrivillaga, C. \& Brown, T.W. (2018). Primary descriptions of defence mechanisms employed by neotropical salamanders (Bolitoglossa, Oedipina, Nototriton, and Cryptotriton sp.: Plethodontidae) in Cusuco National 
Park, Honduras. IRCF Reptiles \& Amphibians 25: 99-103.

Campbell, J.A., Smith, E.N., Streicher, J., Acevedo, M.E. \& Brodie, J. (2010). New salamanders (Caudata: Plethodontidae) from Guatemala, with miscellaneous notes on known species. Miscellaneous Publications, Museum of Zoology, University of Michigan 200: 1-66.

Duellman, W.E. \& Trueb, L. (1986). The Biology of Amphibians. The John Hopkins University Press, Baltimore, Maryland, pp. 506.

Frost, D.R. (2020). Amphibian Species of the World: an Online Reference. Version 6.1 (30/03/2020). Database accessible at https://amphibiansoftheworld.amnh.org/index.php. American Museum of Natural History, New York, USA. doi.org/10.5531/db.vz.0001

Hess, A.J., Itgen, M.W., Firneno, T.J., Nifong, J.C., \& Townsend, J.H. (2017). Microsympatry in cryptic lowland salamanders (Caudata: Plethodontidae: Bolitoglossa subgenus Nanotriton) from north-western Honduras: implications for taxonomy and regional biogeography. Journal of Zoological Systematics and Evolutionary Research 55: 150-155. doi: 10.1111/jzs.12151
Kohler, G. (2011). Amphibians of Central America. Offenbach, Herpeton Verlag, pp. 380 ISBN 3-936180-33-4

Parra-Olea, G., García-París, M. \& Wake, D.B. (2004). Molecular diversification of salamanders of the tropical American genus Bolitoglossa (Caudata: Plethodontidae) and its evolutionary and biogeographic implications. Biological Journal of the Linnaean Society 81: 325-346.

Phillips, J. \& Nicholson, K. (2013). Bolitoglossa lignicolor Prehensility. Herpetological Review 44: 489.

Rovito, S.M., Parra-Olea, G., Lee, D. \& Wake, D.B. (2012a). A new species of Bolitoglossa (Amphibia, Caudata) from the Sierra de Juárez, Oaxaca, Mexico. ZooKeys 185: 5571. doi: doi.org/10.3897/zookeys.185.1146

Rovito, S.M., Parra-Olea, G., Vázquez-Almazán, C.R., LunaReyes, R. \& Wake, D.B. (2012b). Deep divergences and extensive phylogeographic structure in a clade of lowland tropical salamanders. BMC Evolutionary Biology 12: 1-16.

Accepted: 21 March 2020 